Land and Natural Resources, in requiring maritime local planning authorities to report forthwith on their progress in facilitating an immediate roviow of development control of the coust. It also welcomes the initiative for a longer term and continuing assessment of existing and potential recreational, industrial and other pressures on the coast to form a basis for future control policy and the review of development plans. The National Parks Commission now hopes to start a series of conferences wih the maritime planning authoritios in the spring of 1966 when the additional staff needed should be available. Appended to the report are extracts from the address of the Minister of Land and Natural Resources, Mr. F. Willey, to the Conference of National Park Authoritics at Harrogate in May 1965, and also from the closing address of Lord Strang, chairman of the Commission.

The Commission records the concurrence of the Water Resources Board in the Commission's general policy of water conservation, that National Parks should be immune from any incursion until every other alternative has been thoroughly explored. It adds, moreover, that its own view is that no new large reservoirs should be constructed in the Lake District, and that if it is really necessary for water to be obtained from the Lako District it should be taken from rivers at or near their tidal limits. In this context it rocords its interest in the results of preliminary investigations of the projects for barrages across Morecambe Bay, the Solway Firth and the River Dee, in which the Ministor of Land and Natural Resources should be taking a much more determined part. The Commission remains strongly opposed to the draft Manchester Order, 1965, proposing to abstract water from Ullswater, and extracts from the evidence given at the enquiry which the Minister of Housing and Local Government held at Kendal in June and July 1965 are appended.

\title{
WATER RESOURCES IN BRITAIN
}

$\mathrm{T}$ HE second annual report of the Water Resources Board* covers the year ended September 30,1965 , in which major changes in ministorial responsibility for water questions undor the Water Resources Act, 1963, were mado. Under an Order which came into operation on April 1, 1965, the Ministor of Land and Natural Resources shares with the Minister of Housing and Local Government and the Secretary of State for Wales the duties imposed by Section 1 of the 1963 Act and became responsible for the Board and for furctions relating to invostigations and research into conserving and aug. menting water resourcos and to hydrometric schemes. When the Board was given the opportunity of commenting on the detailed provisions of the Order before it was finally made, it took the view that while the overall apportionment of Ministerial responsibility was essentially a matter for the Govornment, it was highly desirable that any transfer of functions should not prejudice either the unified management of water resources by river authorities in their respective areas, or the national planning of the development of those resources for which the Board and the Minister of Housing and Local Government had been made responsible by the 1963 Act. The Board considers that the new Order avoids such prejudico.

The staff of the Board are civil servants and the Board accopted the initial staff complement prepared for the purposes of the Financial Momorandum to the Bill for the 1963 Act. Following a Civil Service Commission competition in November-Docomber 1964, fifteen of the twenty enginoering posts were filled; most of the new staff took up thoir appointments by May 1965 and the Board hoped to fill vacancies in some grades by the autumn of 1965 . In discussions with the Treasury, the Ministry of Housing and Local Government, the Department of Education and Seience and the Geological Survey regarding the futuro of the Water Department of the Survey, it was generally accepted that it would be desirable for one body to handle both the surface and ground-water aspects of water resources management and that the sensiblo course was to transfer responsibility for advising on ground-water for the Survey to the Board, leaving responsibility for basic research with the Survey. Acoordingly, part of the complement of the Water Dopartmont of the Survey was transferred to the Board, these twelve posts bringing tho Board's staff complemont to seventy-two, of which ten posts are at present vacant. Tho five main Divisions are geology, hydrometry, liaison and promotion, planning, and research.

* Water Resources Act, 1963. Second Annual Report of the Water Resources Board for the year ending 30th September, 1965. Pp. $\mathrm{v}+40$. (London: H.M.S.O., 1965.) 3s, $6 d$. net.
Rainfall during the year was 35.7 in., compared with an average of $35.59 \mathrm{in}$, during 1916-50. The Board is concerned particularly with two aspects of the Gas Act, 1965, namoly, the proceduro whereby the Gas Council will be authorized to store gas underground, and the provisions for redressing any injury subsequontly sustained by statutory water undertakers or other abstractors us a result of the storage. The Board was satisfied that the Bill adequately protected the interosts of water users and hopes to agree with the Gas Council on a procedure for recoiving early warning of any proposals.

After discussing the existing liaison with river authorities and other bodies, the Board attempts an interim assessment of the water situation in England and Wales before describing the actual methods of assessing water resourcos. It dismisses rather too lightly the practicability of desalting sea-water, except for small plants to meet peak domands, for example, at holiday resorts, and discount the possibility of any large plant operating before about 1980 . The possibility of storage in estuaries is recognized, but the cost of distribution and the problems of silting, navigation and fish migration, land drainage and ecology, and of effluent treatment and disposal are emphasized, the outlook being essentially negative rather than positive or constructive. Unless the cost of water from barrage schemes and from desalting processes becomes comparable to the cost of water produced by conventional means and the costs of distribution are no greater, the Board believes that between 1975 and 2000 most of Britain's requirements over and above those met by ground-water developments will be met by the further dovelopment of upland storage sites in the north and west, coupled with the transfer of water in rivor channels.

The Board seems to be quite unaware of the Nature Conservancy's vicw that upland storage is an inappropriate and obsolete method or of the social costs of upland storage, and their chapter on augmenting water resources is unsatisfactory and disturbing. It is lacking in understanding and puts no urgeney behind the onquiries into the feasibility of the Morecambe Bay and Solway Barrage Schemes, though it is critical of some of the Manchester Corporation's proposals regarding the Longdendale Valley reservoirs. Meanwhile, two ad hoc technical committees have been convened, one dealing with the Thames Catchment area north of the Tharnes and the other with the part south of the river.

The chapter on research is more satisfactory. The Board's broad approach is to identify needs and then consider whether one or other of the existing research bodies in this field could carry out any necessary work, only undertaking research itself when this is the bost and 
most economical course or there is no other suitable alternative. At present, attention is concentrated on four main topics: artificial recharge of aquifiers; river regulation; desalination; and automatic data processing. Studies have been initiated to define those areas where recharge might be undertaken, particular attention being paid to ground-water conditions in the London basin. On the dissolution of the Department of Scientific and Industrial Research, the Board assumed responsibility for the grant of $£ 33,000$ to the Water Research Association to investigate the present state of technology on desalination and the economic feasibility of desalination in Britain.

A final chapter of the report looking at the year ahead admits that there must be a strong initial presumption against any development which might damage the appearance of the National Parks or interfere with public access. Nevertheless, after agreeing that some areas should be held against any development, the Board claims that the total area of the Parks is too large to be sacrosanct from any change. While it maintains that before a firm proposal is made affecting a Park, every possible alternative must be explored and that sometimes such search has not been enough, it adds that it moy sometimes be necessary to allow development within a National Park. Clearly the Water Resources Board is another public authority seeking to judge its own cause; certainly its activities will need to be carefully watched.

\section{TRACHOMA}

$\mathrm{T}$ RACHOMA, one of the most widespread of all diseases, is believed to affect $400-500$ million people and is the greatest single cause of blindness and impaired vision. The disease is defined in the third report of the World Health Organization Expert Committee on Trachoma (1962) as a "specific communicable keratoconjunctivitis, usually of chronic evolution, caused by an agent belonging to the psittacosis-lymphogranuloma-trachoma (PLT) group of atypical viruses, and characterized by follicles, papillary hyperplasia, pannus and, in its later stages, cicatrization".

The most recent and complete survey of the global distribution of trachoma is that by Bietti, Freycke and Vozza. In their review, which cites more than 1,100 references to the literature, the fallibility of much of the available statistical information is emphasized; the authors point out that the data provided by health authorities of various countries are based on diverse criteria, making comparisons between countries extremely difficult. Among the methods of collecting information they cite compulsory notification of all cases, estimates based on investigations of the causes of blindness or on the proportion of patients with trachoma attending hospitals and dispensaries, and routine examinations of school children, military recruits or expectunt mothers. They rightly consider that the only reliable method is a properly conducted sampling survey by competent ophthalmologists.

Early in 1959 \& team began work at the Medical Research Council Laboratories in the Gambia, using a specially designed laboratory building generously provided by the Wellcome Foundation. Their investigations have been described in a monograph*.

The eyes of all 401 inhabitants of the Gambian village of Marakissa were examined to determine the prevalence of trachoma and other external eye diseases. All subjects were examined clinically; the presence of trachoma/ inclusion conjunctivitis (TRIC) agent was sought in conjunctival scrapings by inoculation into chick embryos, and by examinations for inclusion bodies; the ocular bacterial flora were also investigated. Classes of the population found to be of particular interest in this initial survey were subsequently re-examined. Ancillary investigations of special relevance to trachoma were also undertaken.

In the first survey TRIC agent infection was found to occur as early as the first year of life: the incidence of clinical trachoma increased to a maximum of 91 per cent in the 5-9 year age group, and afterwards declined progressively with advancing age. It was most commonly acquired after the second year of life, which suggests that

* Medical Research Council. Special Report Series No. 308: Trachoma and
Allied Infections in a Gambian Village. By Shiona Sowa. J. Sowa. Allied Infections in a Gambian Village. By Shiona Sowa, J. Sowa, L. H. Collie
and W. Blyth. Pp. vil $+88+6$ plates. (London: H.M.S.O., 1965.) 208. net. it may be transmitted by close contact with other young children.

More than 80 per cent of the inhabitants had some form of ophthalmic abnormality. Although severe post-trachomatous sequelae were comparatively rare, severe visual defect caused by trachoma was found in 2.5 per cent of the population. No case of complete blindness was attributable to trachoma alone.

The isolation method proved more reliable than the finding of inclusions for demonstrating TRIC agent in the conjunctiva. Thus, in the first survey, virus was isolated from 69 per cent of subjects with second-stage trachoma, whereas inclusions were found in only 47 per cent. The proportion of virus-positive subjects diminished as the disease progressed and with advancing age. TRIC agent was not detected in those with healed trachoma, in normal subjects, or in those with eye diseases other than trachoma. These findings suggest that most, if not all, trachoma in this area is caused by infection with TRIC agent, and that there is no 'carrier' state in non-trachomatous subjects.

The first stage of trachoma may last for 1-2 years, and the second stage from 3 months to at least 2 years. Pannus was present in less than ha]f those with first-stage trachoma, but its incidence increased in the later stages, suggesting that in the Gambia its onset may be considerably delayed. When present it was often not pronounced, and slight neovascularization may disappear without trace. Seasonal variation in climatic conditions did not appear to affect the severity of active trachoma.

The eyes of 79 babies born in Marakissa over a period of three years were examined at frequent intervals for periods up to 2 years or more. Evidence of TRIC agent infection in five infants shortly after birth and isolation of TRIC agent from the genital tracts of three of the mothers suggested that the infants' ophthalmic infection was acquired at birth; in three infants the resulting disease resembled trachoma rather than inclusion conjunctivitis. In eleven other infants, laboratory confirmation of TRIC infection was obtained at times varying from 2 to 24 months after birth. The signs of inflammation at the onset of infection were less severe than in the new-born children; the subsequent course was characterized by the infrequency and late appearance of corneal lesions, and by a relatively high rate of spontaneous cure. These findings support the view that, in some countries at least, there is no clear demarcation between trachoma and inclusion conjunctivitis syndromes.

Only 4 of 384 pecple tested had bacteriologically sterile conjunctivae (one of these had only one sterile conjunctiva). The potential pathogens most frequently isolated were streptococci (53 per cent of subjects), staphylococci (40 per cent) and haemcphilus bacilli ( 3 per cent). All these bacteria were isolated more frequently from younger than from older people, and more frequently from tracho- 